\title{
Quantum dot-induced viral capsid assembling in dissociation buffer
}

\author{
This article was published in the following Dove Press journal: \\ International Journal of Nanomedicine \\ 4 June 2013 \\ Number of times this article has been viewed
}

\section{Ding Gao ${ }^{1,2}$ \\ Zhi-Ping Zhang' \\ Feng $\mathrm{Li}^{3}$ \\ Dong Men' \\ Jiao-Yu Deng' \\ Hong-Ping Wei ${ }^{\prime}$ \\ Xian-En Zhang' \\ Zong-Qiang Cui'}

'State Key Laboratory of Virology, Wuhan Institute of Virology, Chinese Academy of Sciences, Wuhan, ${ }^{2}$ Graduate University of Chinese Academy of Sciences, Beijing, ${ }^{3}$ Division of Nanobiomedicine and i-Lab, Suzhou Institute of Nano-Tech and Nano-Bionics, Chinese Academy of Sciences, Suzhou, People's Republic of China
Correspondence: Xian-En Zhang; Zong-Qiang Cui

State Key Laboratory of Virology, Wuhan Institute of Virology, Chinese Academy of Sciences, No 44, Xiaohongshan, Wuhan, 43007I, People's Republic of China

Tel +86 2787197105

Fax +862787199492

Email x.zhang@wh.iov.cn; czq@wh.iov.cn
Abstract: Viruses encapsulating inorganic nanoparticles are a novel type of nanostructure with applications in biomedicine and biosensors. However, the encapsulation and assembly mechanisms of these hybridized virus-based nanoparticles (VNPs) are still unknown. In this article, it was found that quantum dots (QDs) can induce simian virus 40 (SV40) capsid assembly in dissociation buffer, where viral capsids should be disassembled. The analysis of the transmission electron microscope, dynamic light scattering, sucrose density gradient centrifugation, and cryo-electron microscopy single particle reconstruction experimental results showed that the SV40 major capsid protein 1 (VP1) can be assembled into $\approx 25 \mathrm{~nm}$ capsids in the dissociation buffer when QDs are present and that the QDs are encapsulated in the SV40 capsids. Moreover, it was determined that there is a strong affinity between QDs and the SV40 VP1 proteins $\left(\mathrm{K}_{\mathrm{D}}=2.19 \mathrm{E}-10 \mathrm{M}\right)$, which should play an important role in QD encapsulation in the SV40 viral capsids. This study provides a new understanding of the assembly mechanism of SV40 virus-based nanoparticles with QDs, which may help in the design and construction of other similar virus-based nanoparticles.

Keywords: quantum dots, simian virus 40, self-assembly, encapsulation, virus-based nanoparticles

\section{Introduction}

Virus capsids are delicate protein shells that are formed by self-assembly. ${ }^{1}$ Due to their useful characteristics, such as a uniform nanoscale size, ${ }^{2}$ symmetric structure, ${ }^{3}$ easy fabrication, ${ }^{4}$ and easy modification, ${ }^{5}$ viral capsids have been used as nanoplatforms. ${ }^{6}$ Various types of virus-based nanoparticles (VNPs) have been developed. ${ }^{7-12}$ Typically, VNPs are spherical shells formed from viral capsid proteins, which can encapsulate inorganic nanoparticles (eg, quantum dots [QDs], gold nanoparticles, and magnetic nanoparticles), ${ }^{13}$ resulting in hybridized nanoparticles. ${ }^{6}$ Some of these VNPs also show potential for use in biosensors and biomedicine. ${ }^{14}$ However, the encapsulation and assembly mechanisms of the hybridized VNPs are still unknown. ${ }^{15}$

In the authors' previous studies, several types of VNPs based on the simian virus 40 (SV40) capsid, which is assembled from the SV40 major virus capsid protein 1 (VP1), were developed. For example, VNPs of SV40 capsids that encapsulated QDs were constructed and it was demonstrated that the VNPs act the same as wild type SV40 during the initial infection steps. ${ }^{16}$ The capsid protein VP1 was used to encapsulate QDs with different surface coatings, including negatively, neutrally, and positively charged QDs. ${ }^{17}$ Gold nanoparticles were also assembled in the SV40 capsids. ${ }^{18}$ The SV40 VNPs have the ability to guide the assembly of discrete, three-dimensional (3D), hybrid 
nanoarchitectures with one QD inside a VNP and a tunable number of gold nanoparticles attached to the outer surface of the VNP. ${ }^{19,20}$ By changing the ratio of wild type VP1 to mutant VP1, the number of gold nanoparticles attached to the VNPs can be controlled. ${ }^{21}$ With more studies on these constructed SV40 VNPs being conducted, the assembly mechanism of SV40 capsids with inorganic nanoparticles becomes an intriguing subject. Are there basic principles for viral capsid assembly with inorganic nanoparticles? Here, an interesting phenomenon was found where QDs can induce SV40 capsid assembly in the dissociation buffer, which may provide some insight into the assembly mechanism.

Normally, the SV40 major capsid protein VP1 can only be assembled into capsids in an assembly buffer that contains assembly promotion factors, such as certain ionic strengths, ${ }^{22-24}$ concentrations of calcium ion $\left(\mathrm{Ca}^{2+}\right)$, or nucleic acids. ${ }^{25-28}$ However, in this study, it was discovered that VP1 can be assembled into capsids when there are QDs in the dissociation buffer and that the QDs are encapsulated in the SV40 capsids. Analysis of the transmission electron microscopy (TEM), dynamic light scattering (DLS), sucrose density gradient centrifugation (SDGC), and cryo-electron microscopy (cryo-EM) single particle reconstruction data verified this result. Moreover, the affinity measurements showed that there is a strong interaction between the QDs and SV40 VP1 proteins.

\section{Material and methods}

\section{Expression and purification of SV40 VPI}

The pET32a plasmid containing the SV40 VP1 DNA sequence was transformed into the Escherichia coli Rosetta ${ }^{\mathrm{TM}}$ (DE3) strain (EMD Millipore, Billerica, MD, USA). The cells were shaken at $200 \mathrm{rpm}$ and $37^{\circ} \mathrm{C}$ to an optical density at $600 \mathrm{~nm}$ of 0.6 and induced with $1 \mathrm{mM}$ of isopropyl- $\beta-\mathrm{D}-$ thiogalactopyranoside at $25^{\circ} \mathrm{C}$ and $150 \mathrm{rpm}$ for 9 hours. The bacteria were washed with a high-salt assembly buffer $(10 \mathrm{mM}$ tris[hydroxymethyl] aminomethane hydrochloride ( $\mathrm{pH} 7.2), 1$ M sodium chloride, $1 \mathrm{mM}$ calcium chloride, and 5\% glycerol). The cells were pelleted again and then resuspended in the high-salt assembly buffer. After resuspension, the cells were sonicated. The fragments were centrifuged at 10,000 rpm for 30 minutes at $4^{\circ} \mathrm{C}$. To deposit the protein, a saturated ammonium sulfate solution was added dropwise at a rate of $0.5 \mathrm{~mL} / \mathrm{minute}$ into the stirring supernatant. When the protein solution became opaque, it was continually stirred for 30 minutes. After the turbid liquid was sedimented at $10,000 \mathrm{rpm}$ for 30 minutes at $4^{\circ} \mathrm{C}$, the sediment was dissolved in $25 \mathrm{~mL}$ of the high-salt assembly buffer. The undissolved proteins were removed by centrifugation at $10,000 \mathrm{rpm}$ for 30 minutes. The protein solution was concentrated to $5 \mathrm{~mL}$ in an Amicon ${ }^{\circledR}$ Ultra-25 centrifuge tube (30 kDa molecular weight cutoff; EMD Millipore) for preparation of the SV40 VNPs. After ultracentrifugation at 55,000 rpm for 1 hour in a Type 90 Ti rotor (Beckman Coulter, Brea, CA, USA), the VNPs were collected and then dissolved in $30 \mathrm{~mL}$ of the dissociation buffer (10 $\mathrm{mM}$ tris[hydroxymethyl] aminomethane hydrochloride ( $\mathrm{pH} 8.8$ ), $250 \mathrm{mM}$ sodium chloride, $2 \mathrm{mM}$ ethylenediaminetetraacetic acid, $30 \mathrm{mM} \beta$-mercaptoethanol, and 5\% glycerol) for 24 hours. The excess VNPs were removed by ultracentrifugation at 55,000 rpm for 1 hour, and the VP1 pentamers were stored at $-80^{\circ} \mathrm{C}$. A Bio-Rad Protein Assay Kit II \#500-0002. (Bio-Rad Laboratories, Hercules, CA, USA) was used to measure the VP1 concentration.

\section{Preparation of 3-mercaptopropionic acid (MPA)-modified QDs}

Core/Shell cadmium selenide/zinc sulfide QDs Powder (QSP-610-05, 5 mg; Ocean NanoTech, Springdale, AR, USA) with a $600 \mathrm{~nm}$ emission wavelength was dissolved in $1 \mathrm{~mL}$ of toluene. Then, $200 \mu \mathrm{L}$ of QDs were mixed with $200 \mu \mathrm{L}$ of excessive MPA ( $\geq 99 \%$; Sigma-Aldrich, St Louis, MO, USA) and vortexed in a vortex oscillator for 40 minutes. The sediment was collected at $6000 \mathrm{~g} /$ minute for 5 minutes. After discarding the supernatant, the QD sediments were resuspended in a borate saline buffer ( $\mathrm{pH}$ 8.2). QDs dissolved in water were centrifuged at 15,000 rpm for 15 minutes, and the supernatant was stored at $4{ }^{\circ} \mathrm{C}$.

\section{VPI assembly in buffers}

The VP1 was mixed with the MPA-QDs (molar ratio was 60:1) and dialyzed against the dissociation buffer or assembly buffer (10 $\mathrm{mM}$ tris[hydroxymethyl]aminomethane hydrochloride ( $\mathrm{pH} 7.2$ ), $1 \mathrm{mM}$ calcium chloride, $250 \mathrm{mM}$ sodium chloride, and $5 \%$ glycerol) at $4{ }^{\circ} \mathrm{C}$ overnight by dialysis bag (molecular weight cutoff is $3000 \mathrm{Da}$ ). The buffer was renewed every 6 hours.

\section{SDGC}

The solution containing the VP1 protein and MPA-QDs was layered on top of the $10 \%-40 \%$ sucrose gradient prepared using the dissociation buffer or assembly buffer and sucrose in an SW40 Ti rotor (Beckman) transparent centrifuge tube, followed by centrifugation at $38,000 \mathrm{rpm}$ and $4{ }^{\circ} \mathrm{C}$ for 4.5 hours. The VP1 and VP1-QD solutions were absorbed from the top to the bottom in eight separate mean fractions (F0-F7), and the protein content in each fraction 
was determined by sodium dodecyl sulfate polyacrylamide gel electrophoresis. The fluorescence band of the VP1-QD solution in dissociation buffer was collected using the excitation produced by a portable ultraviolet lamp, and this was followed by TEM analysis.

\section{TEM statistics}

For the TEM analysis, a carbon-coated copper grid was covered with a sample drop for 1 minute, removed with filter paper and negatively stained for 30 seconds. The samples were identified using a Tecnai ${ }^{\mathrm{TM}} \mathrm{G}^{2} 20$ TWIN electron microscope (FEI Company, Hillsboro, OR, USA) operating at $200 \mathrm{kV}$ and imaged with a Cantega G2 bottommounted CCD TEM camera (Olympus Corporation, Tokyo, Japan). Cryo-EM micrographs were obtained by a Titan $\operatorname{Krios}^{\mathrm{TM}}(300 \mathrm{kV}$; FEI). The TEM images were processed and analyzed using iTEM (Olympus). The particle number statistics of four micrographics (25,000× magnification) were determined for each sample by eye, and the diameters statistics of VNPs ( $\approx 400$ particles) were measured by iTEM software (version 5.0).

\section{DLS}

DLS measurements of MPA-QDs, VP1-QDs, and VP1 in the dissociation buffer without glycerol were taken using a Zetasizer $^{\circledR}$ Nano ZS (Malvern Instruments, Malvern, UK), as previous described. ${ }^{16,29}$ The VP1 concentration of each sample was $0.6 \mathrm{mg} / \mathrm{mL}$ and the MPA-QD concentration was $4 \mu \mathrm{M}$. The samples were filtered using a $0.22 \mu \mathrm{m}$ syringe filter. The dispersant refraction index was 1.330 (water) and the material refraction index was 1.450 (protein).

\section{$3 \mathrm{D}$ reconstruction}

The 3D reconstruction of VP1-QDs was carried out by using the EMAN2 software suite. ${ }^{30}$ The particles were selected with the e2boxer program from the cryo-EM images for reconstruction. Initial models were generated by the 22 initial model program. The final model was Gaussian filtered to generate low-pass filtering for a 0.05 cutoff frequency. In the initial model generation and 3D refinement, icosahedral symmetry was applied. The final 3D reconstruction was visualized with Chimera software (University of California, Santa Cruz, CA, USA). ${ }^{31}$

\section{Affinity measurements}

Finally, the binding kinetics of VP1 to MPA-QDs and VP1 pentamers were measured using the ForteBio ${ }^{\circledR}$ BioLayer Interferometry of the Octet ${ }^{\circledR}$ RED96 system (Pall Corporation,
Port Washington, NY, USA). VP1 was modified with biotins. First, the VP1 proteins were dialyzed to the phosphate buffered saline dissociation (PBS) buffer (conventional PBS buffer with $2 \mathrm{mM}$ ethylenediaminetetraacetic acid and $30 \mathrm{mM} \beta$-mercaptoethanol added). Then, triple molarity of a biotin agent (NHS-LC-LC-Biotin; Thermo Fisher Scientific, Waltham, MA, USA) was mixed with VP1 proteins and incubated for 1 hour. Then, the mixture was dialyzed to the PBS dissociation buffer for removing redundant biotin. All interaction analyses were conducted at $30^{\circ} \mathrm{C}$ in the PBS dissociation buffer. Streptavidin sensor tips were prewet for 5 minutes in the buffer immediately prior to use, and the 96-well microplates used in the Octet were filled with $200 \mu \mathrm{L}$ of the sample or buffer per well and agitated at $1000 \mathrm{rpm}$. Biotinylated VP1 $(350 \mu \mathrm{g} / \mathrm{mL})$ was loaded to saturation onto the streptavidin capture biosensors, and then the loaded biosensors were washed in the buffer for 120 seconds and transferred to wells containing MPA-QDs at concentrations of $100 \mathrm{nM}, 50 \mathrm{nM}, 25 \mathrm{nM}, 12.5 \mathrm{nM}, 6.25 \mathrm{nM}$, and $0 \mathrm{nM}$ in the buffer, and containing VP1 at concentrations of $2988 \mathrm{nM}$, $1493.6 \mathrm{nM}, 746.8 \mathrm{nM}, 373.4 \mathrm{nM}, 186.7 \mathrm{nM}, 93.36 \mathrm{nM}$, and $0 \mathrm{nM}$. The binding kinetics of VP1 to SV40 genome doublestranded DNA (dsDNA) was also measured. SV40 genome dsDNA was amplified by polymerase chain reaction with biotin-16-dUTP (Biotin-16-dUTP; Roche Diagnostics, Basel, Switzerland) from pSV21-C plasmid. The biotinylated SV40 genome dsDNA was loaded to the sensors, and the association of dsDNA with VP1 was measured at VP1 concentrations of $390.8 \mathrm{nM}, 195.3 \mathrm{nM}, 97.7 \mathrm{nM}, 48.8 \mathrm{nM}$, $24.4 \mathrm{nM}, 12.2 \mathrm{nM}$, and $0 \mathrm{nM}$. The associations were measured for 15 minutes and the dissociations were measured for 30 minutes. The kinetic parameters $\left(\mathrm{K}_{\text {on }}\right.$ and $\left.\mathrm{K}_{\text {off }}\right)$ and affinities $\left(\mathrm{K}_{\mathrm{D}}\right)$ were calculated from a nonlinear global fit of the data using the Octet software (version 6.4.0.20) with a mass transport model.

\section{Results Expression and purification of VPI pentamers}

As described previously, ${ }^{18}$ wild type SV40 VP1 was expressed in E. coli and purified using ammonium sulfate precipitation and ultracentrifugation. After maintaining the VP1 in dissociation buffer for 2 days, SV40 VP1 existed as pentamers dissolved in the buffer, and there were no VNPs (Figure 1).

\section{QDs induce VPI assembly into VNPs}

Interestingly, when MPA-QDs were added to the SV40 VP1 that was dissolved in the dissociation buffer and 

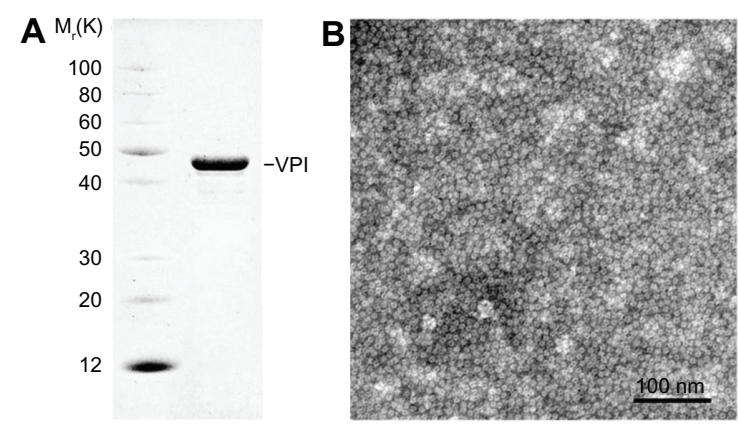

Figure I (A) Sodium dodecyl sulfate polyacrylamide gel electrophoresis of VPI. (B) Transmission electron microscope image of VPI pentamers.

Abbreviation: VPI, major virus capsid protein I.

incubated at $4{ }^{\circ} \mathrm{C}$ overnight (VP1-QD sample), assembly particles of VNPs-QDs were formed (Figure 2A). VNPsQDs show a core/shell structure. For each of the VNPsQDs, an electron dense core of QD was encapsulated in the gray protein shell of VNP (Figure 2A). When there were no QDs, VP1 could not assemble into VNPs in the dissociation buffer during an overnight incubation at $4{ }^{\circ} \mathrm{C}$ (the control sample VP1; Figure 2B). TEM and statistical analysis verified that the number of assembled VNPs in the protein solution with QDs was significantly larger than in the solution without QDs (Figure 2C). The mean diameter of the VNPs encapsulating the QDs was calculated to be $25.5 \pm 2.0 \mathrm{~nm}$; the modal diameter is $25.5 \mathrm{~nm}(\approx 400$ particles).

\section{Characterizing the diameters and surface potentials of QD-induced VNPs}

DLS measurements were conducted to detect the distribution of the hydrodynamic diameter for the VP1-QDs formed in the dissociation buffer. As shown in Figure 3, the mean hydrodynamic diameter of the VP1-QDs was $25.8 \mathrm{~nm}$, which is similar to the diameter measured using TEM $(25.5 \mathrm{~nm})$. When there were no QDs, the diameter of VP1 pentamers was $10.6 \mathrm{~nm}$ in the dissociation buffer. Meanwhile, the diameter of MPA-QDs was $5.4 \mathrm{~nm}$ (Figure 3). To understand the electrostatic interaction between the VP1 pentamers and MPA-QDs, the surface potentials were measured using DLS. The results show that the surface potentials of the VP1 pentamers and MPA-QDs were $-4.71 \mathrm{mV}$ and $-16.3 \mathrm{mV}$, respectively. This result indicates that there was no strong
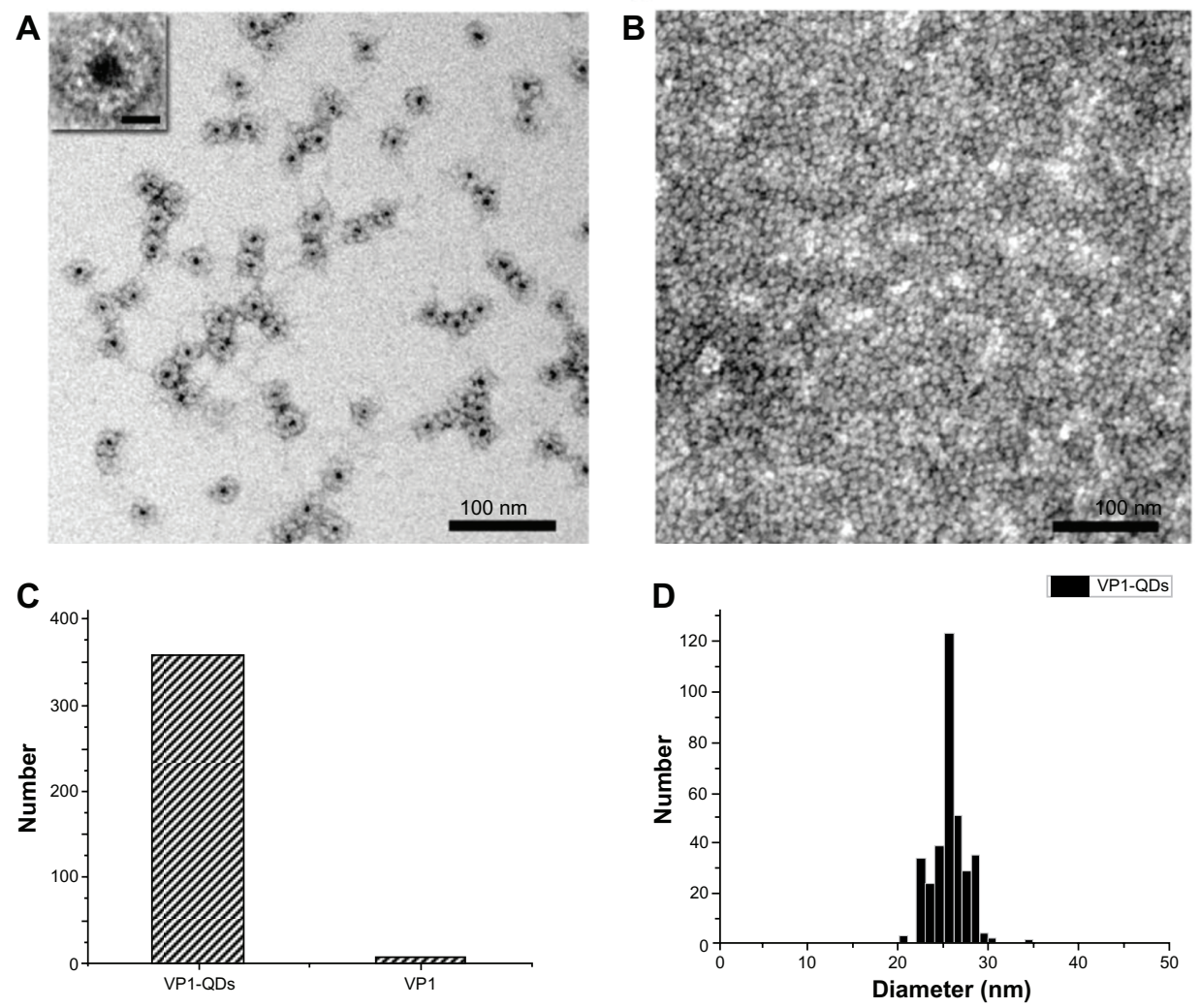

Figure 2 Transmission electron microscope images of simian virus 40 VPI (A) mixed with 3-mercaptopropionic acid-modified quantum dots and (B) alone in the dissociation buffer. The zoomed version in (A) shows a single particle of the virus-based nanoparticle with quantum dots, with a core/shell structure of an electron dense core (quantum dots) encapsulated in the gray VPI protein shell (scale bar $=10 \mathrm{~nm}$ ). (C) The yields of virus-based nanoparticles for VPI-QDs and VPI were calculated based on four random $25,000 \times$ transmission electron micrographs. (D) Diameter statistics of virus-based nanoparticles in VPI-QDs.

Abbreviations: VPI, major virus capsid protein I; VPI-QDs, major virus capsid protein I with quantum dots. 


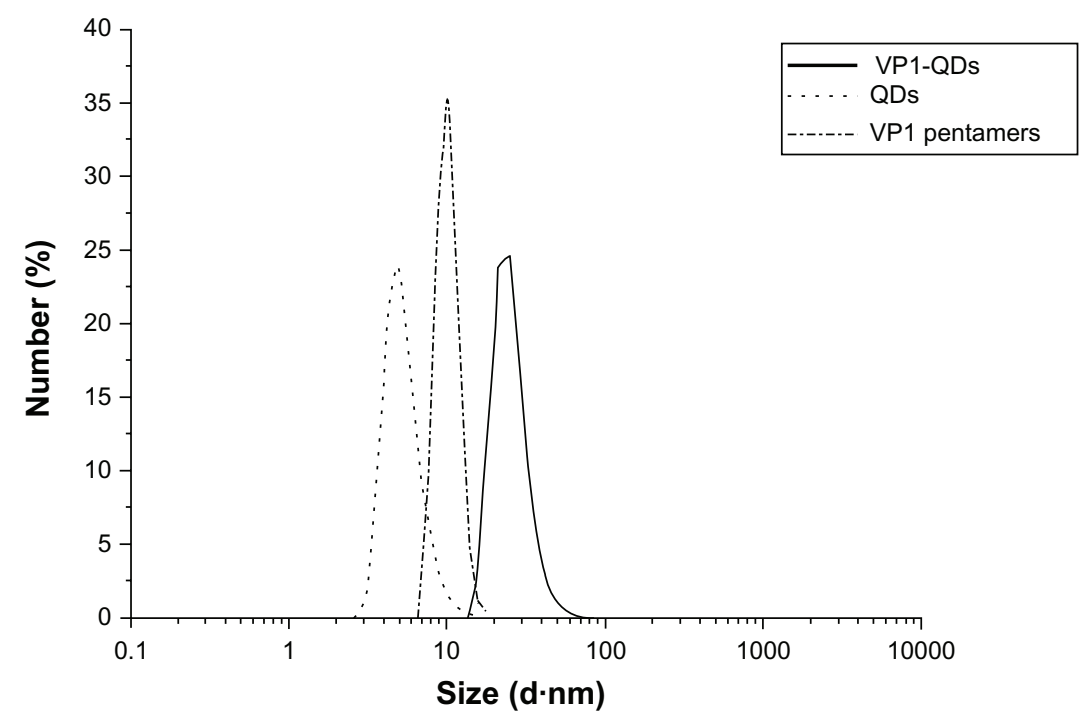

Figure 3 Diameter measurements of VPI-QDs, QDs, and VPI pentamers using dynamic light scattering.

Abbreviations: QDs, quantum dots; VPI, major virus capsid protein I; VPI-QDs, major virus capsid protein I with quantum dots.

surface electrostatic interaction between the VP1 protein and MPA-QDs.

\section{Purification and determination of VNPs encapsulating QDs}

The VP1-QDs were also analyzed and purified by SDGC. As shown in Figure 4A, the fluorescence of the QDs was condensed into a narrow band in the SDGC tube.
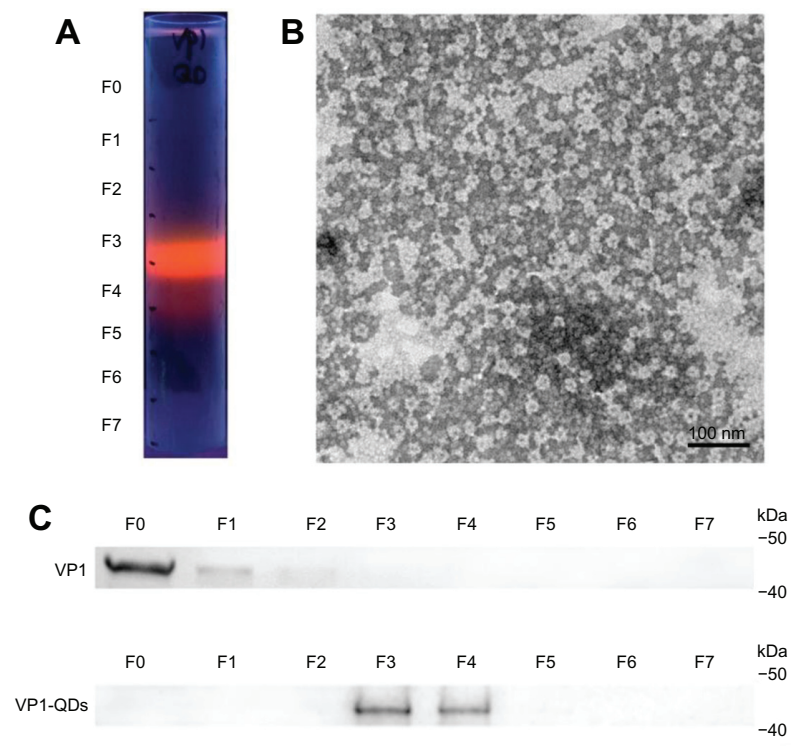

Figure 4 (A) Sucrose density gradient centrifugation fluorescence image of VPIQDs in the dissociation buffer. (B) The F3 band was excised for transmission electron microscope analysis. (C) The VPI (upper) and VPI-QDs (lower) were analyzed by sucrose density gradient centrifugation, and the F0-F7 bands were used for sodium dodecyl sulfate polyacrylamide gel electrophoresis analysis.

Abbreviations: VPI, major virus capsid protein I; VPI-QDs, major virus capsid protein I with quantum dots.
This fluorescent band was excised and dialyzed against the dissociation buffer to desugar it. The TEM micrograph showed the regular structure of the VNP-QD particles in the fluorescent band sample (Figure 4B). The sample in the SDGC tube in Figure 4A was also divided into eight fractions (F0-F7), which were then collected for sodium dodecyl sulfate polyacrylamide gel electrophoresis analysis (Figure 4C). In Figure 4C, SDGC of the VP1 without QDs in the dissociation buffer was conducted as a control. From Figure 4C, it can clearly be seen that the VP1 protein in the VP1-QD sample was distributed in the F3-F4 fractions, which correspond to the fluorescence bands of the VNP-QDs. For the VP1 samples without QDs, the protein was mainly distributed in the F0 fraction. The SDGC analysis results of VP1-QDs assembled in the dissociation buffer (Figure S1A) were compared with the VP1-QDs assembled in assembly buffer (Figure S1B) as a control. The fluorescent bands stayed at the same position in the centrifuge tube for the two analyses (Figure S1).

\section{D reconstruction of $\mathrm{VNPs}$ with $\mathrm{QDs}$}

To further characterize the structure of VNPs for the purified VP1-QDs, the 3D reconstruction was constructed using cryo-EM single particle analysis with EMAN2 software. ${ }^{30}$ Figure 5 shows the cryo-EM micrograph of VP1-QDs, which presented as a dark spot (QD) surrounded by a gray shell (VP1 proteins) (Figure 5A), and 3D reconstruction structure of VP1-QDs (Figure 5B). From the cryo-EM 3D reconstruction, it can be seen that VNP-QDs have a regular icosahedron structure. This result further verifies that QDs induced the assembly of virus capsids. 

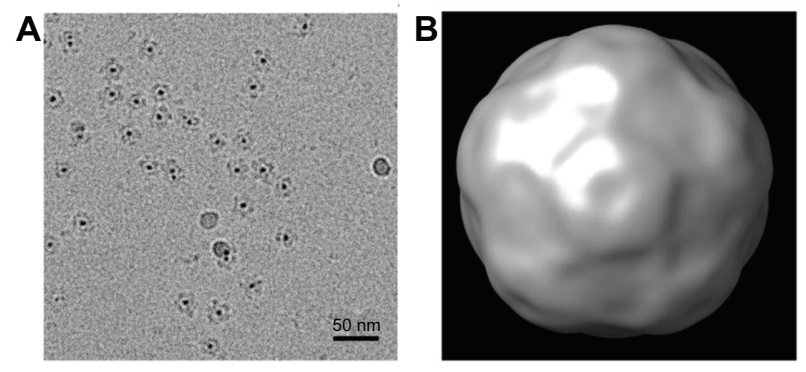

Figure 5 (A) Cryo-electron micrograph of major virus capsid protein I with quantum dots assembled in the dissociation buffer. (B) Three-dimensional reconstruction structure of the virus-based nanoparticles.

\section{Affinity between QDs and VPI pentamers}

To further understand the assembly of VP1 and QDs, a quantitative analysis of their affinities was conducted using the Octet RED96 system. Briefly, biotinylated VP1 proteins were loaded onto streptavidin sensors and balanced in the dissociation buffer to obtain baseline signals. Then, QDs with a series of concentration gradients were added to the sensors to acquire association signals and dissociation signals (Figure 6). From the baseline signals, binding signals, and dissociation signals, the affinities of VP1 with QDs could be calculated. Using this method, the $\mathrm{K}_{\mathrm{D}}$ value of the VP1 pentamers with QDs was determined to be $2.19 \mathrm{E}-10 \mathrm{M}$ (Table 1). Additionally, the $\mathrm{K}_{\mathrm{D}}$ value of the VP1 pentamers was 1.32E-7 M (Figure S2 and Table S1) and that of the
VP1 with SV40 genome dsDNA was 1.11E-8 M (Figure S3 and Table S2).

\section{Discussion}

Normally, SV40 VP1 proteins cannot assemble into VNPs in the dissociation buffer. However, in this work it was found when QDs were added, VNPs encapsulating QDs were assembled. These VNPs exhibited a uniform diameter and regular shape, just as the T $=1$ VNPs of SV40 did. In the dissociation buffer, the disulfide bonds are broken by $\beta$-mercaptoethanol, and the $\mathrm{Ca}^{2+}$ that stabilizes the VNP structures is chelated by ethylenediaminetetraacetic acid..$^{27,32}$ The low ionic strength and the lack of disulfide bonds lead to the collapse of the VNPs. This means that the concentrations of salt and $\mathrm{Ca}^{2+}$ significantly contribute to the formation of VNPs. ${ }^{22-24,28,33}$ However, QDs can promote VP1 to assemble into VNPs in the absence of a high concentration of salt and $\mathrm{Ca}^{2+}$, indicating that the QD-induced assembly of VNPs might occur through a different path.

A potential analysis showed that the QDs and VP1 pentamers both carry weak, negative charges, which indicates that the electrostatic attraction between the QDs and pentamers may not be the determining factor of the assembly. In previous work, it was found that there is no correlation between the encapsulation efficiency and the surface charge of the QDs. ${ }^{17}$ These results indicate that the electrostatic

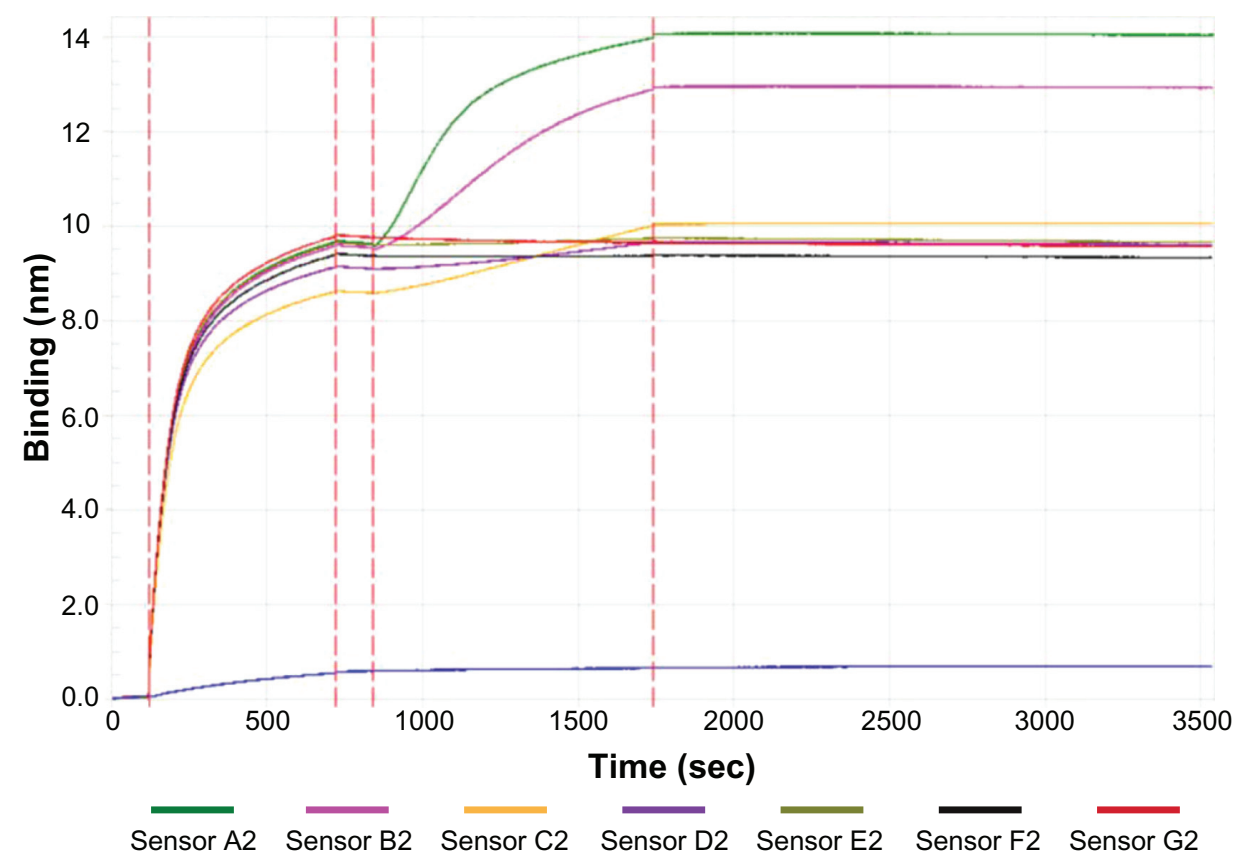

Figure 6 Affinity measurement signal curves of major virus capsid protein I pentamers with quantum dots (for different concentrations).

Notes: The whole process is as follows: baseline (0-120 seconds), major virus capsid protein I pentamers loading (120-720 seconds), baseline (720-840 seconds), quantum dots association (840-1740 seconds), and quantum dots dissociation (I740-3540 seconds). Sensors A2-G2 represent a quantum dots concentration of I00 nM, $50 \mathrm{nM}, 25 \mathrm{nM}$, $12.5 \mathrm{nM}, 6.25 \mathrm{nM}, 3.125 \mathrm{nM}$, and $0 \mathrm{nM}$, respectively (the blue curve shows the nonspecific binding to the sensor of quantum dots). 
Table I Affinities of the major virus capsid protein I pentamers with 3-mercaptopropionic acid-modified quantum dots

\begin{tabular}{|c|c|c|c|c|c|c|c|}
\hline Index & Concentration (nM) & Response & $K_{D}(M)$ & $\mathrm{K}_{\mathrm{on}}\left(\mathrm{Ms}^{-1}\right)$ & $K_{\text {on }}$ error & $K_{\text {dis }}\left(\mathbf{s}^{-1}\right)$ & $\mathbf{K}_{\mathrm{dis}}$ error \\
\hline I & 100 & 4.5036 & $2.19 \mathrm{E}-10$ & $2.50 \mathrm{E}+04$ & $7.27 \mathrm{E}+0 \mathrm{I}$ & $5.48 \mathrm{E}-06$ & $0.00 \mathrm{E}+00$ \\
\hline 2 & 50 & 3.4939 & $2.19 \mathrm{E}-10$ & $2.50 \mathrm{E}+04$ & $7.27 \mathrm{E}+0 \mathrm{I}$ & $5.48 \mathrm{E}-06$ & $0.00 \mathrm{E}+00$ \\
\hline 3 & 25 & 1.557 & $2.19 \mathrm{E}-10$ & $2.50 \mathrm{E}+04$ & $7.27 \mathrm{E}+0 \mathrm{I}$ & $5.48 \mathrm{E}-06$ & $0.00 \mathrm{E}+00$ \\
\hline 4 & 12.5 & 0.6879 & $2.19 \mathrm{E}-10$ & $2.50 \mathrm{E}+04$ & $7.27 \mathrm{E}+0 \mathrm{I}$ & $5.48 \mathrm{E}-06$ & $0.00 \mathrm{E}+00$ \\
\hline 5 & 6.25 & 0.27 & $2.19 \mathrm{E}-10$ & $2.50 \mathrm{E}+04$ & $7.27 \mathrm{E}+0 \mathrm{I}$ & $5.48 \mathrm{E}-06$ & $0.00 \mathrm{E}+00$ \\
\hline 6 & 3.125 & 0.1291 & $2.19 \mathrm{E}-10$ & $2.50 \mathrm{E}+04$ & $7.27 \mathrm{E}+0 \mathrm{I}$ & $5.48 \mathrm{E}-06$ & $0.00 \mathrm{E}+00$ \\
\hline
\end{tabular}

Note: Index I-6 show the $\mathrm{K}_{\mathrm{D}}, \mathrm{K}_{\mathrm{on}}$, and $\mathrm{K}_{\text {dis }}$ values of major virus capsid protein I with quantum dots concentration gradient from $100 \mathrm{nM}$ to $3 . \mathrm{I} 25 \mathrm{nM}$.

force should not play an important role in the assembly of SV40 VNPs.

Interestingly, it was discovered that there is high affinity between VP1 and MPA-QDs $\left(\mathrm{K}_{\mathrm{D}}=2.19 \mathrm{E}-10 \mathrm{M}\right)$. The $\mathrm{K}_{\mathrm{D}}$ value of VP1 and SV40 genome dsDNA was 1.11E-8 M in the same condition, which is similar to the reported $\mathrm{K}_{\mathrm{D}}$ value of VP1 and DNA (5.3E-9 M). ${ }^{34,35}$ Thus, the affinity between VP1 and MPA-QDs is similar to the affinity between VP1 and DNA. It is thought that the interaction between VP1 and DNA drives the virus assembly and DNA encapsulation. ${ }^{26,27,34}$ The strong interaction between VP1 and MPA-QDs may play a role similar to that of the interaction between VP1 and DNA, and this interaction may act as the driving force behind the assembly of QD VNPs encapsulated in viral capsids. It was reported that the amino acids histidine, cysteine, methionine, and tryptophan have high affinity with cadmium selenide/zinc sulfide QDs, ${ }^{36}$ so it is supposed that these amino acids of VP1 should play roles in triggering the assembly between VP1 and QDs. The interaction among the VP1 pentamers was also measured. The $\mathrm{K}_{\mathrm{D}}$ value was 1.32E-7 M, which shows a weak affinity (Table S1). This work offers a possible mechanism by which QDs facilitate the formation of VNP. Like DNA, the strong interaction of VP1 and QD cause the binding of VP1 to the QDs, which act as scaffolds that increase local concentrations of VP1 and as an allosteric effector that alter the tertiary structure of VP1. ${ }^{27,34}$ The strong interaction between VP1 and QDs

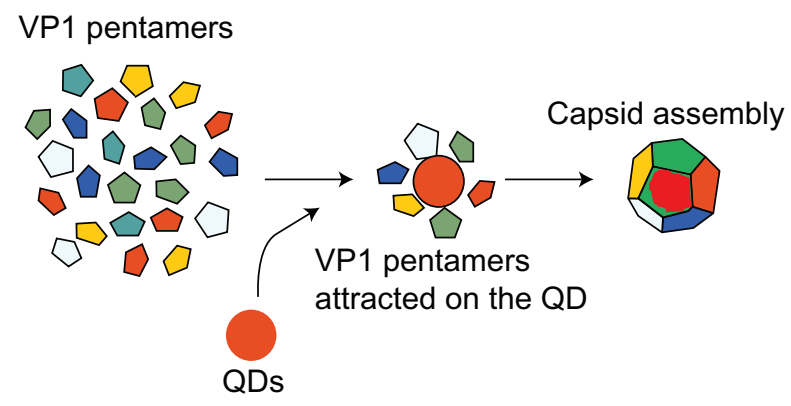

Figure 7 Schematic procedure of QD-induced virus capsid assembly. Abbreviations: QD, quantum dots; VPI, major virus capsid protein I. causes the binding of the VP1 proteins to the QDs, and this interaction results in the conformational change of VP1, which plays the similar role as the high concentrations of salt and $\mathrm{Ca}^{2+} .{ }^{24,28}$ The tight binding of VP1 with QDs stabilizes the VNP structures.

Based on the above experiments and analysis, it is inferred that the QD-induced capsid assembly is as follows (Figure 7): first, the QDs attract the VP1 pentamers surrounding them via a strong interaction. Then, the VP1 pentamers are rearranged on the QD surfaces due to the weak interactions between the pentamers $^{37,38}$ and the uniform, regular, and stable VNPs with QDs are assembled.

\section{Conclusion}

An interesting phenomenon was observed where QDs can induce the assembly of the SV40 major capsid protein VP1 into VNPs in dissociation buffer, whereas in previous studies the SV40 capsids encapsulated QDs in assembly buffer. TEM, DLS, SDGC, and cryo-EM single particle reconstruction experiments verified that VP1 can be assembled into regular viral capsids when there are QDs in the dissociation buffer and that the QDs are encapsulated in the SV40 capsids. Furthermore, a high affinity was discovered between the QDs and SV40 VP1 proteins, and the $\mathrm{K}_{\mathrm{D}}$ value was calculated to be $2.19 \mathrm{E}-10 \mathrm{M}$. This study provides a new understanding of the assembly mechanism of SV40 VNP-QDs, which may be helpful in designing other new nanoarchitectures.

\section{Acknowledgments}

ZQ Cui and ZP Zhang are supported by the National Nano Project (number 2011CB933600 and 2012CB721000). The authors also thank the support from the Chinese Academy of Sciences (number XDA01020403) and the National Natural Science Foundation of China (number 31200755).

\section{Disclosure}

The authors report no conflicts of interest in this work. 


\section{References}

1. Zlotnick A, Mukhopadhyay S. Virus assembly, allostery and antivirals. Trends Microbiol. 2011;19(1):14-23.

2. Caspar DLD, Klug A. Citation Classics: physical principles in the construction of regular viruses. Cold Spring Harbor Symp Quant Biol. 1962;27:1-24. Current Contents/Life Sciences. 1984;27(4):15.

3. Johnson JE, Chiu W. Structures of virus and virus-like particles. Curr Opin Struct Biol. 2000;10(2):229-235.

4. Jutz G, Boker A. Bionanoparticles as functional macromolecular building blocks - a new class of nanomaterials. Polymer. 2011;52(2): 211-232.

5. Su ZH, Wang QA. A hierarchical assembly process to engineer a hydrophobic core for virus-like particles. Angew Chem Int Ed Engl. 2010;49(52):10048-10050.

6. Bronstein LM. Virus-based nanoparticles with inorganic cargo: what does the future hold? Small. 2011;7(12):1609-1618.

7. Comellas-Aragones M, Engelkamp H, Claessen VI, et al. A virus-based single-enzyme nanoreactor. Nat Nanotechnol. 2007;2(10):635-639.

8. Stubenrauch K, Gleiter S, Brinkmann U, Rudolph R, Lilie H. Conjugation of an antibody $\mathrm{Fv}$ fragment to a virus coat protein: cell-specific targeting of recombinant polyoma-virus-like particles. Biochem J. 2001;356(Pt 3):867-873.

9. Aljabali AAA, Lomonossoff GP, Evans DJ. CPMV-polyelectrolytetemplated gold nanoparticles. Biomacromolecules. 2011;12(7): 2723-2728.

10. Ma YJ, Nolte RJ, Cornelissen JJ. Virus-based nanocarriers for drug delivery. Adv Drug Del Rev. 2012;64(9):811-825.

11. Schmidt U, Gunther C, Rudolph R, Bohm G. Protein and peptide delivery via engineered polyomavirus-like particles. FASEB J. 2001;15(9):1646-1648.

12. Mao C, Flynn CE, Hayhurst A, et al. Viral assembly of oriented quantum dot nanowires. Proc Natl Acad Sci U S A. 2003;100(12):6946-6951.

13. Wang Q, Bao Y, Ahire J, Chao Y. Co-encapsulation of biodegradable nanoparticles with silicon quantum dots and quercetin for monitored delivery. Adv Healthc Mater. 2013;2(3):459-466.

14. Singh P, Gonzalez MJ, Manchester M. Viruses and their uses in nanotechnology. Drug Dev Res. 2006;67(1):23-41.

15. Aniagyei SE, Dufort C, Kao CC, Dragnea B. Self-assembly approaches to nanomaterial encapsulation in viral protein cages. J Mater Chem. 2008;18(32):3763-3774.

16. Li F, Zhang ZP, Peng J, et al. Imaging viral behavior in mammalian cells with self-assembled capsid-quantum-dot hybrid particles. Small. 2009;5(6):718-726.

17. Li F, Li K, Cui ZQ, et al. Viral coat proteins as flexible nano-buildingblocks for nanoparticle encapsulation. Small. 2010;6(20):2301-2308.

18. Wang T, Zhang Z, Gao D, et al. Encapsulation of gold nanoparticles by simian virus 40 capsids. Nanoscale. 2011;3(10):4275-4282.

19. Li F, Gao D, Zhai X, et al. Tunable, discrete, three-dimensional hybrid nanoarchitectures. Angew Chem Int Ed Engl. 2011;50(18): 4202-4205.

20. Li F, Chen H, Zhang Y, et al. Three-dimensional gold nanoparticle clusters with tunable cores templated by a viral protein scaffold. Small. 2012;8(24):3832-3838.
21. Li F, Chen Y, Chen H, et al. Monofunctionalization of protein nanocages. J Am Chem Soc. 2011;133(50):20040-20043.

22. Salunke DM, Caspar DLD, Garcea RL. Polymorphism in the assembly of polyomavirus capsid protein VP1. Biophys J. 1989;56(5):887-900.

23. Salunke DM, Caspar DLD, Garcea RL. Self-assembly of purified polyomavirus capsid protein VP1. Cell. 1986;46(6):895-904.

24. Kanesashi SN, Ishizu K, Kawano MA, et al. Simian virus 40 VP1 capsid protein forms polymorphic assemblies in vitro. $J$ Gen Virol. 2003;84(Pt 7):1899-1905.

25. Mukherjee S, Abd-El-Latif M, Bronstein M, Ben-nun-Shaul O, Kler S, Oppenheim A. High cooperativity of the SV40 major capsid protein VP1 in virus assembly. PLoS One. 2007;2(8):e765.

26. Mukherjee S, Kler S, Oppenheim A, Zlotnick A. Uncatalyzed assembly of spherical particles from SV40 VP1 pentamers and linear dsDNA incorporates both low and high cooperativity elements. Virology. 2010; 397(1):199-204.

27. Tsukamoto H, Kawano MA, Inoue T, et al. Evidence that SV40VP1DNA interactions contribute to the assembly of 40-nm spherical viral particles. Genes Cells. 2007;12(11):1267-1279.

28. Li PP, Naknanishi A, Tran MA, et al. Importance of VP1 calciumbinding residues in assembly, cell entry, and nuclear entry of simian virus 40. J Virol. 2003;77(13):7527-7538.

29. Huang X, Bronstein LM, Retrum J, et al. Self-assembled virus-like particles with magnetic cores. Nano Lett. 2007;7(8):2407-2416.

30. Tang G, Peng L, Baldwin PR, et al. EMAN2: an extensible image processing suite for electron microscopy. J Struct Biol. 2007;157(1): 38-46.

31. Pettersen EF, Goddard TD, Huang CC, et al. UCSF chimera a visualization system for exploratory research and analysis. J Comput Chem. 2004;25(13):1605-1612.

32. Kawano MA, Xing L, Tsukamoto H, Inoue T, Handa H, Cheng RH. Calcium bridge triggers capsid disassembly in the cell entry process of simian virus 40. J Biol Chem. 2009;284(50):34703-34712.

33. Nilsson J, Miyazaki N, Xing L, et al. Structure and assembly of a $\mathrm{T}=1$ virus-like particle in BK polyomavirus. $J$ Virol. 2005;79(9): 5337-5345.

34. Li PP, Nakanishi A, Shum D, et al. Simian virus 40 VP1 DNA-binding domain is functionally separable from the overlapping nuclear localization signal and is required for effective virion formation and full viability. J Virol. 2001;75(16):7321-7329.

35. Moreland RB, Montross L, Garcea RL. Characterization of the DNAbinding properties of the polyomavirus capsid protein VP1. J Virol. 1991;65(3):1168-1176.

36. Peelle BR, Krauland EM, Wittrup KD, Belcher AM. Design criteria for engineering inorganic material-specific peptides. Langmuir. 2005;21(15):6929-6933.

37. Liddington RC, Yan Y, Moulai J, Sahli R, Benjamin TL, Harrison SC. Structure of simian virus 40 at 3.8-A resolution. Nature. 1991; 354(6351):278-284.

38. Stehle T, Gamblin SJ, Yan Y, Harrison SC. The structure of simian virus 40 refined at 3.1 A resolution. Structure. 1996;4(2):165-182. 


\section{Supplementary materials}

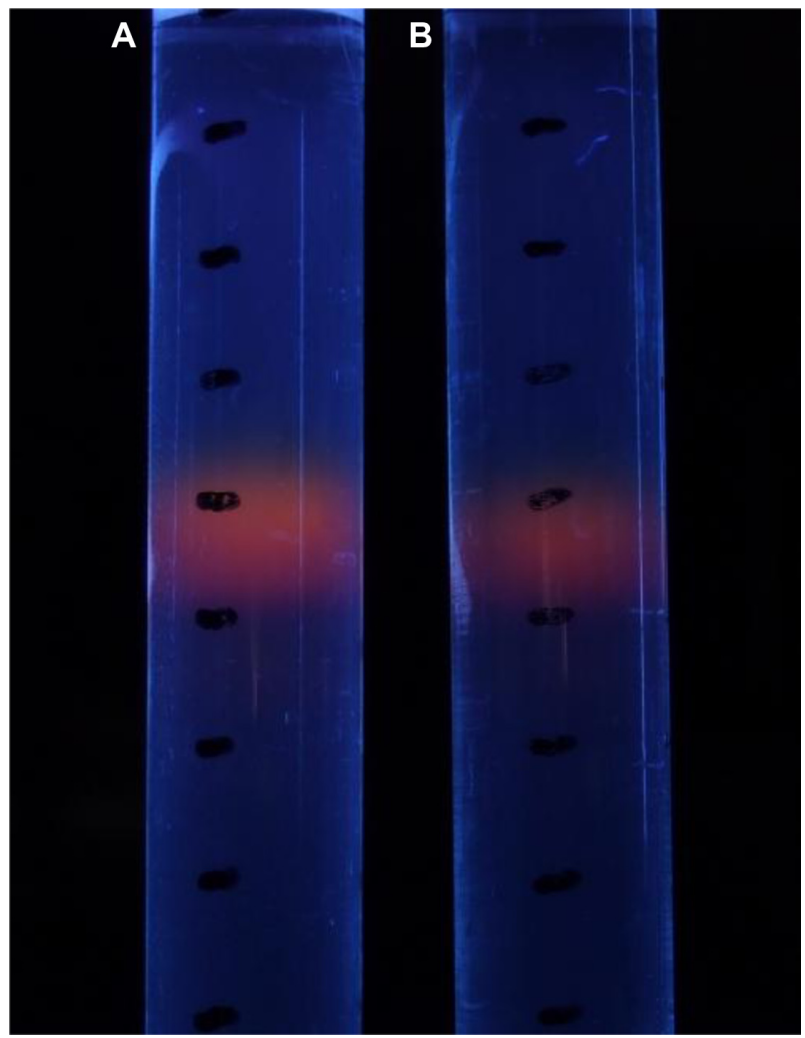

Figure SI Sucrose density gradient centrifugation fluorescence image of major virus capsid protein I with quantum dots in (A) dissociation buffer and (B) assembly buffer.

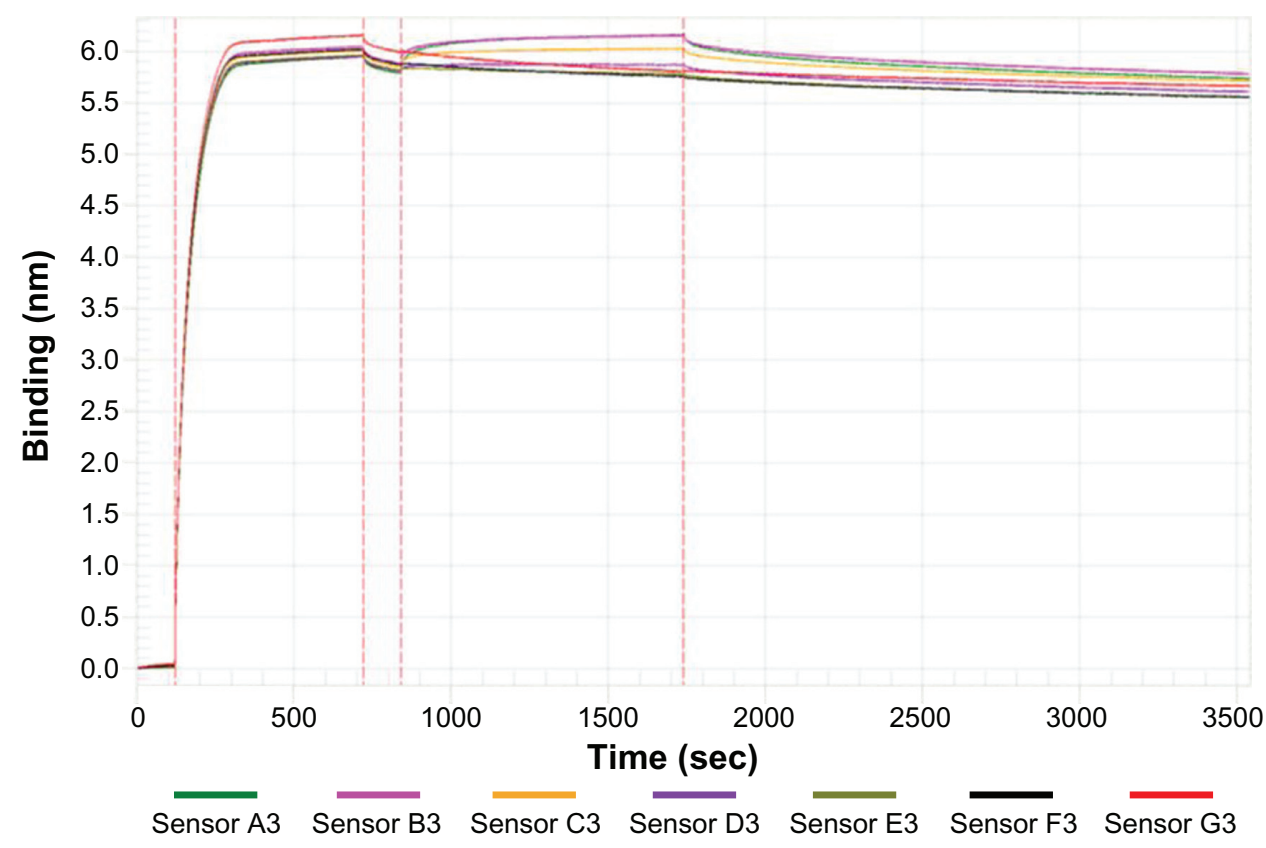

Figure S2 Affinity measurement signal curves of major virus capsid protein I pentamers with pentamers (for different concentrations).

Notes: The whole process is as follows: baseline (0-120 second), major virus capsid protein I pentamers loading (I20-720 seconds), baseline ( $720-840$ seconds), pentamers association (840-1740 seconds), and pentamers dissociation (1740-3540 seconds). Sensors A3-G3 represent major virus capsid protein I pentamers concentrations of $2988 \mathrm{nM}, 1493.6 \mathrm{nM}, 746.8 \mathrm{nM}, 373.4 \mathrm{nM}, 186.7 \mathrm{nM}, 93.36 \mathrm{nM}$, and $0 \mathrm{nM}$, respectively. 


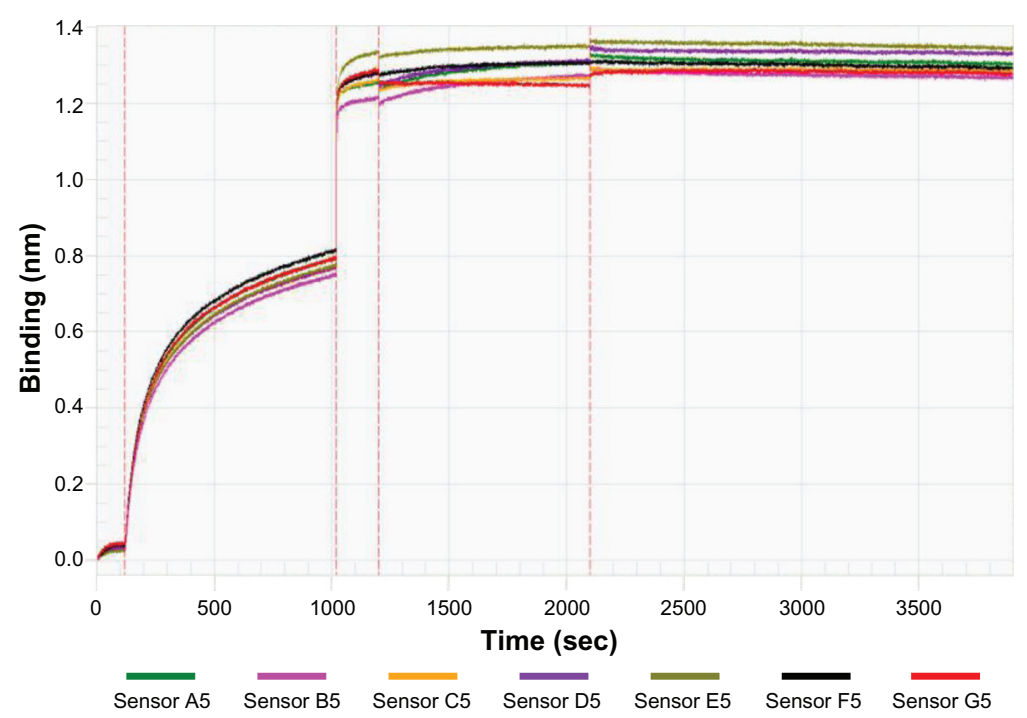

Figure S3 Affinity measurement signal curves of simian virus 40 genome DNA with major virus capsid protein I pentamers (for different concentrations).

Notes: The whole process is as follows: baseline (0-120 seconds), simian virus 40 genome DNA loading (I20-1020 seconds), baseline (I020-I200 seconds), pentamers association (1200-2100 seconds), and pentamers dissociation (2100-3900 seconds). Sensors A5-G5 represent major virus capsid protein I pentamers concentrations of $390.8 \mathrm{nM}, 195.3 \mathrm{nM}, 97.7 \mathrm{nM}, 48.8 \mathrm{nM}, 24.4 \mathrm{nM}, 12.2 \mathrm{nM}$, and $0 \mathrm{nM}$, respectively.

Table SI Affinities between the major virus capsid protein I pentamers

\begin{tabular}{|c|c|c|c|c|c|c|c|}
\hline Index & Concentration (nM) & Response & $K_{D}(M)$ & $\mathrm{K}_{\mathrm{on}}\left(\mathrm{Ms}^{-1}\right)$ & $\mathrm{K}_{\text {on }}$ error & $\mathbf{K}_{\text {dis }}\left(\mathbf{s}^{-1}\right)$ & $\mathbf{K}_{\text {dis }}$ error \\
\hline $\mathrm{I}$ & 2988 & 0.5692 & I.32E-07 & $1.50 \mathrm{E}+05$ & $7.89 E+04$ & I.99E-02 & $1.04 \mathrm{E}-02$ \\
\hline 2 & 1493.6 & 0.4631 & I.32E-07 & $1.50 \mathrm{E}+05$ & $7.89 \mathrm{E}+04$ & I.99E-02 & $1.04 \mathrm{E}-02$ \\
\hline 3 & 746.8 & 0.3706 & I.32E-07 & $1.50 \mathrm{E}+05$ & $7.89 \mathrm{E}+04$ & I.99E-02 & I.04E-02 \\
\hline 4 & 373.4 & 0.2543 & I.32E-07 & $1.50 \mathrm{E}+05$ & $7.89 \mathrm{E}+04$ & I.99E-02 & $1.04 \mathrm{E}-02$ \\
\hline 5 & 186.7 & 0.1585 & I.32E-07 & $1.50 \mathrm{E}+05$ & $7.89 \mathrm{E}+04$ & I.99E-02 & $1.04 \mathrm{E}-02$ \\
\hline 6 & 93.36 & 0.0679 & I.32E-07 & $1.50 \mathrm{E}+05$ & $7.89 \mathrm{E}+04$ & I.99E-02 & I.04E-02 \\
\hline
\end{tabular}

Note: Index I-6 show the $\mathrm{K}_{\mathrm{D}}, \mathrm{K}_{\mathrm{on}}$, and $\mathrm{K}_{\text {dis }}$ values of major virus capsid protein I pentamers with concentration gradient from $2988 \mathrm{nM}$ to $93.36 \mathrm{nM}$.

Table S2 Affinities between simian virus 40 genome DNA and the major virus capsid protein I pentamers

\begin{tabular}{|c|c|c|c|c|c|c|c|}
\hline Index & Concentration (nM) & Response & $K_{D}(M)$ & $\mathrm{K}_{\mathrm{on}}\left(\mathrm{Ms}^{-1}\right)$ & $K_{o n}$ error & $K_{\text {dis }}\left(\mathbf{s}^{-1}\right)$ & $\mathbf{K}_{\text {dis }}$ error \\
\hline 1 & 390.8 & 0.076 & I.IIE-08 & $1.84 \mathrm{E}+04$ & $1.73 \mathrm{E}+02$ & $2.04 \mathrm{E}-04$ & I.58E-06 \\
\hline 2 & 195.3 & 0.0804 & I.IIE-08 & $1.84 \mathrm{E}+04$ & $1.73 E+02$ & $2.04 \mathrm{E}-04$ & $1.58 \mathrm{E}-06$ \\
\hline 3 & 97.7 & 0.0314 & I.IIE-08 & I.84E+04 & $1.73 E+02$ & $2.04 \mathrm{E}-04$ & $1.58 \mathrm{E}-06$ \\
\hline 4 & 48.8 & 0.0711 & I.IIE-08 & I.84E+04 & $1.73 E+02$ & $2.04 \mathrm{E}-04$ & $1.58 \mathrm{E}-06$ \\
\hline 5 & 24.4 & 0.0269 & I.IIE-08 & $1.84 \mathrm{E}+04$ & $1.73 E+02$ & $2.04 \mathrm{E}-04$ & $1.58 \mathrm{E}-06$ \\
\hline 6 & 12.2 & 0.027 I & I.IIE-08 & $1.84 \mathrm{E}+04$ & $1.73 E+02$ & 2.04E-04 & I.58E-06 \\
\hline
\end{tabular}

Note: Index I-6 show the $\mathrm{K}_{\mathrm{D}}, \mathrm{K}_{\mathrm{o}}$, and $\mathrm{K}_{\text {dis }}$ values of major virus capsid protein I pentamers with concentration gradient from $390.8 \mathrm{nM}$ to $\mathrm{I} 2.2 \mathrm{nM}$.

International Journal of Nanomedicine

\section{Dovepress}

\section{Publish your work in this journal}

The International Journal of Nanomedicine is an international, peerreviewed journal focusing on the application of nanotechnology in diagnostics, therapeutics, and drug delivery systems throughout the biomedical field. This journal is indexed on PubMed Central, MedLine, CAS, SciSearch ${ }^{\circledR}$, Current Contents $₫ /$ Clinical Medicine,
Journal Citation Reports/Science Edition, EMBase, Scopus and the Elsevier Bibliographic databases. The manuscript management system is completely online and includes a very quick and fair peer-review system, which is all easy to use. Visit http://www.dovepress.com/ testimonials.php to read real quotes from published authors. 